\title{
Spatial and temporal variability of sessile benthos in shallow Mediterranean marine caves
}

\author{
Simona Bussotti*, Antonio Terlizzi, Simonetta Fraschetti, Genuario Belmonte, \\ Ferdinando Boero
}

Laboratorio di Zoologia e Biologia Marina, DiSTeBA, Università di Lecce, CoNISMa, 73100 Lecce, Italy

\begin{abstract}
Hypotheses on the spatial and temporal distribution of sessile assemblages in submerged marine caves have rarely been tested. Classically, the distribution of cave benthos has been related mainly to the physical gradients along the exterior-interior axis. Using a multifactorial sampling design, we examined the distribution of species assemblages within 3 different caves in Southern Italy. Non-destructive sampling was repeated at 4 different times over a period of 11 mo. Results showed an overall pattern of change in the structure of the assemblages along the exterior-interior axis of the 3 caves (i.e. among sectors). Significant differences in species assemblages, however, were also observed within sectors (i.e. among areas), and changes in assemblages varied inconsistently with time and among caves. This result suggests a high complexity of the processes determining spatio-temporal distribution patterns in marine caves, which are context- and scale-dependent. Results also showed the uniqueness of these assemblages, which has important implications for their conservation and management.
\end{abstract}

KEY WORDS: Marine caves - Distribution patterns - Sessile benthos - Mediterranean Sea · Conservation Resale or republication not permitted without written consent of the publisher

\section{INTRODUCTION}

Spatio-temporal variability in the distribution of populations and species assemblages is a common perception in the ecological literature (e.g. Levin 1992, Gaston \& McArdle 1993, Boero 1994, Brown 1995, Boero et al. 2004). However, quantitative information on distribution patterns across relevant scales (and understanding of the processes causing or maintaining them) is confined to a small number of habitats and geographic areas and is mainly focussed on either few individual taxa, or sets of interacting species (Schneider 1994, Fraschetti et al. 2005). More quantitative information about the distribution patterns of marine species assemblages over different spatial and temporal scales is needed to support sound habitat management and conservation.

Earlier studies of Mediterranean marine caves showed that unique faunistic and ecological features characterize these habitats (Pérès \& Picard 1964, Riedl
1966, Harmelin et al. 1985, Bianchi et al. 1996, Harmelin \& Vacelet 1997, Chevaldonné \& Lejeusne 2003). Most of these studies provided inventories of biodiversity, and preliminary descriptions of distribution patterns of species assemblages (see Riedl 1966 and references therein).

Surprisingly, in spite of a vast literature describing species composition, distribution patterns and ecological features (Riedl 1966, Ott \& Svoboda 1976, Bussotti et al. 2002, Cicogna et al. 2003) few quantitative frameworks have been developed for testing hypotheses on the processes determining spatial and temporal variation of sessile assemblages of submerged marine caves (for exceptions see Gili et al. 1986, Benedetti-Cecchi et al. 1996, 1998). This is most likely due to logistical constraints limiting quantitative investigations: marine caves are less amenable to fieldwork than shallow subtidal and intertidal zones.

In a first attempt to describe the distribution of sessile benthos within marine caves, Riedl (1966) 
distinguished 6 faunistic zones mostly on the basis of the distribution of algae and hydroids. Pérès \& Picard (1964) described horizontal zonation patterns of cave benthos, identifying 'semi-obscure' (located in the part of the cave that receives light) and 'obscure' biocoenoses (located in the completely dark parts of the cave, with reduced seawater circulation). Species richness, biological cover, and biomass have often been reported to decrease towards the inner parts of the caves (e.g. Laborel \& Vacelet 1958, Riedl 1966, Bianchi et al. 1996). Attenuations of light and water movement along the exterior-interior axis were considered as the driving forces for such changes (Riedl 1966, Cinelli et al. 1977, Harmelin et al. 1985, Gili et al. 1986). In fact, the abrupt decrease in water renewal usually determines oligotrophic conditions in the dark cave recesses due to filtering, sedimentation, and degradation of organic particles (Buss \& Jackson 1981, Fichez 1990, Palau et al. 1991, Garrabou \& Flos 1995 but cf. Airoldi \& Cinelli 1997).

Relevant discrepancies between observed distribution patterns of assemblages in these systems and these classical models have often been reported (e.g. Harmelin 1969, Balduzzi et al. 1989, Benedetti-Cecchi et al. 1998, Corriero et al. 2000, Martì et al. 2004a,b). Internal topography, presence or absence of secondary openings, size, exposure, depth, and possible presence of hydrothermal springs were identified as interacting with the main physical gradients inside caves, causing patterns of heterogeneity different from those expected. Little emphasis has generally been given to proper quantification of small-scale patchiness, reflecting the view that in marine caves physical factors are paramount in setting distribution patterns of populations and assemblages, whereas biotic interactions play a major role in more benign environments, where recruitment rates are high (Balduzzi et al. 1989). However, small-scale patchiness is also frequent in submarine caves. BenedettiCecchi et al. (1996) revealed large differences in species colonization on a scale of a few metres. Variation in larval and food supply (Airoldi \& Cinelli 1996), and post-settlement events have been invoked as processes generating these patterns.

In the Salento Peninsula in SE Italy (Fig. 1a), subtidal habitats are characterized by a substrate (mostly calcarenitic) conducive to the formation of large cavities: in $100 \mathrm{~km}$ of rocky coast, about 70 submarine caves have been mapped (see: www.tamug.tamu.edu/ cavebiology/Research/research.html). The aim of this study was to conduct a mensurative experiment (Hurlbert 1984) in order to describe the distribution patterns of benthic assemblages in submerged marine caves. We used a structured sampling design to quantify variation in sessile assemblages within and across different positions in caves and their consistency through time. The tested hypotheses about spatial patterns of assemblages were driven by the consideration that, beside the most obvious environmental gradients, other sources of variability need to be properly quantified when describing distribution patterns of benthic organisms in marine caves.

\section{MATERIALS AND METHODS}

Study site. Three marine caves characterized by a similar morphology (simple horizontal tunnels, single semi-submerged entrance, presence of air chambers and similar groundwater seeps) were studied near Santa Maria di Leuca (Southern Apulia, SE Italy; Fig. 1b): 'Grotta Piccola del Ciolo' (hereafter CIO; about $100 \mathrm{~m}$ long); 'Grotta di Marinella' (hereafter MAR; about $65 \mathrm{~m}$ long); and 'Galleria della Principessa' (hereafter PRI; about $85 \mathrm{~m}$ long). The caves were located along a $4 \mathrm{~km}$ long portion of a continuous rocky coast, and provided a random subset of shallow (about 6 to $8 \mathrm{~m}$ depth) blind caves in the region. The internal topography of the 3 caves is characterized by a longitudinal axis, parallel to the principal fracture planes characterizing these calcareous cretaceous rocks.

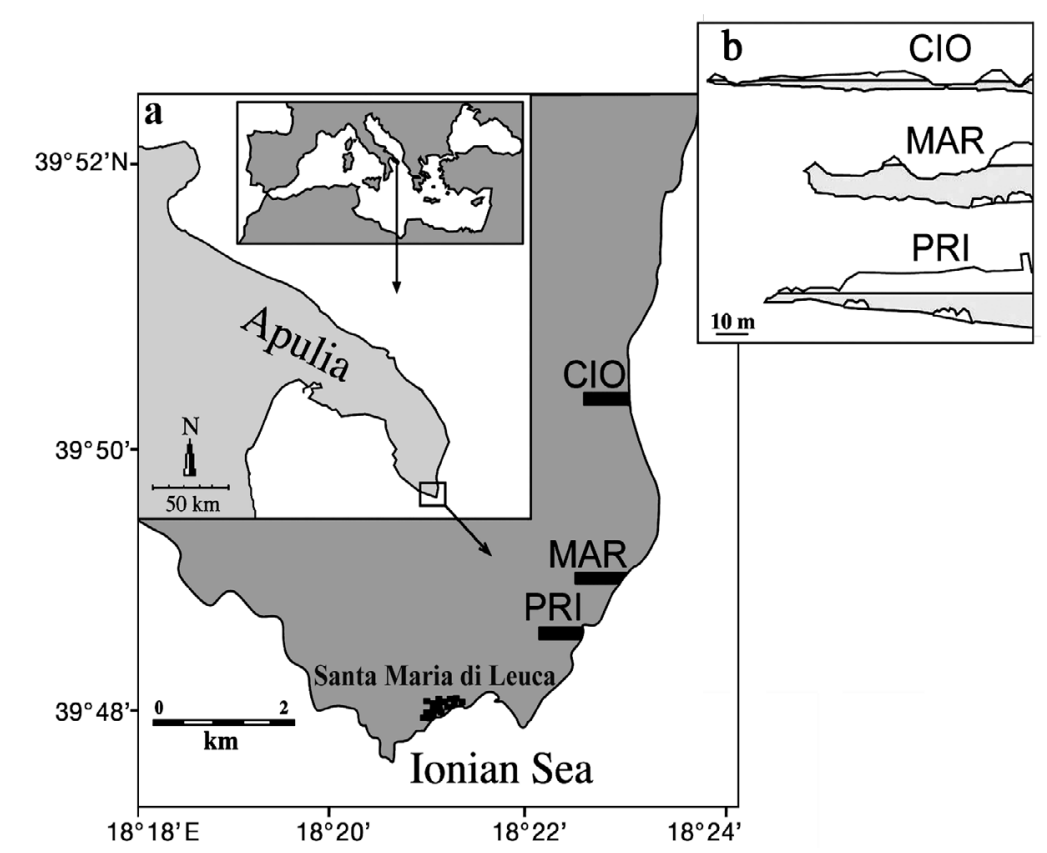

Fig. 1. Caves in the study: (a) geographical location in the Apulia Peninsula, SE Italy; (b) side views, longitudinal axis. CIO: 'Grotta Piccola del Ciolo'; MAR: 'Grotta di Marinella'; PRI: 'Galleria della Principessa' 
Sampling procedures and design. Photographic samples were taken on rocky walls of the caves using a Nikonos V underwater camera with a close-up lens and 2 electronic strobes. In each of the 3 caves, 5 sectors were selected, $0,10,20,40$ and $60 \mathrm{~m}$ from the entrance (hereafter S0, S10, S20, S40, S60). Three random areas of $3 \mathrm{~m}^{2}$ each were identified at each sector, and 8 random $16 \times 23 \mathrm{~cm}$ photo-quadrats were taken in each area. Samples were always taken from vertical surfaces, at least $1 \mathrm{~m}$ above the coarse-sandy substrate. Sampling was repeated on 4 randomly selected occasions in July and November 2000, and February and June 2001 (hereafter T1, T2, T3 and T4, respectively), yielding a total of 1440 units of observation (slides).

The slides were analyzed under a binocular microscope by superimposing a transparent grid subdivided into 24 equal-sized squares. The abundance of sessile organisms (algae and invertebrates) on each slide was determined visually (Dethier et al. 1993, Benedetti-Cecchi et al. 1996) by assigning a score ranging from 0 to 4 to each taxon within each square and adding up these 24 values. Organisms filling less than 0.25 square were given an arbitrary value of 0.5 . Final values were expressed as percentages. Destructive samples were also collected and specialists assisted in the taxonomic identification of organisms.

The sampling design consisted of 4 factors: Time ( $\mathrm{T}$, 4 levels, random), Cave (C, 3 levels, random, crossed with $\mathrm{T})$, Sector ( $\mathrm{S}, 5$ levels, fixed, crossed with $\mathrm{T}$ and $\mathrm{C}$ ) and Area (A, 3 levels, random nested in $\mathrm{S})$, with $\mathrm{n}=8$ replicates per combination of factors.

Multivariate statistical analyses. The multivariate data set included 94 taxa. A distance-based permutational multivariate analysis of variance (PERMANOVA; Anderson 2001, McArdle \& Anderson 2001) was done to test for the significance of terms involved in the full model. The analysis used 4999 random permutations of appropriate units (Anderson \& ter Braak 2003) and was based on $\log _{10}(x+1)$ transformed data. Terms found to be significant in the analysis were examined individually using appropriate pair-wise comparisons. For each time, differences among caves, among sectors and among areas within sectors were represented by non-metric multidimensional scaling (nMDS) ordinations plotting centroids of each area. Centroids were calculated using principal coordinates (see Anderson 2001 for details). All nMDS plots were obtained using the multivariate package PRIMER (Plymouth Marine Laboratory). As most of the variability in PERMANOVA was explained by the $\mathrm{C} \times \mathrm{S}$ interaction term (see associated MS value in Table 2), 3 separate canonical analyses of principal coordinates (CAP) (Anderson \& Willis 2003) were done to show differences in the structure of assemblages across sectors at each of the 3 caves. Distinctness of groups was assessed using leave-one-out allocation success (Lachenbruch \& Mickey 1968). Individual taxa that might be responsible for any group differences seen in the CAP plots were investigated by calculating product-moment correlations of original variables (taxa) with the 2 canonical axes $\left(r_{1}\right.$ and $\left.r_{2}\right)$. These correlations were then plotted as arrows in projection biplots. Only those taxa having relatively strong correlations (i.e. with arrow length of $\sqrt{r_{1}^{2}+r_{2}^{2}} \geq 0.5$ ) were included in the plots.

Univariate statistical analyses. Four-way analyses of variance (ANOVA) were used to examine spatial patterns for single response variables (number of species, total cover). Prior to analyses, the homoge neity of variances was tested using Cochran's test (Underwood 1997). If transformations did not remove heterogeneous variances, the analyses were done on untransformed data but $\alpha$ was set at 0.01 to compensate for the increased likelihood of Type I error. The Student-Newman-Keuls' (SNK) test was used for multiple comparisons of the means (Underwood 1997). Pooling procedures were also used when appropriate according to Winer et al. (1991). ANOVAs were done using the GMAV5 program (University of Sydney).

\section{RESULTS}

\section{Taxonomic composition}

The 94 taxa belonged to 9 phyla (Table 1). The organisms that were not identified at the species level were aggregated into higher taxonomic groups. Moreover, several algae, sponges and bryozoans were not easily identifiable and were aggregated in 8 morphological groups (Steneck \& Dethier 1994): turf-forming algae subdivided into filamentous green algae (genera Cladophora and Chaetomorpha) and filamentous dark algae (including Ceramium spp. and Polysiphonia spp.), thin tubular sheet-like algae (Rhodymenia pseudopalmata and Nithophyllum spp.), encrusting coralline algae (Lithophyllum frondosum, Lithophyllum incrustans, Mesophyllum alternans), encrusting sponges (including Didiscus styliferus and Jaspis johnstonii), massive sponges (Cacospongia spp., Spongia spp., Sarcotragus foetidus), thin encrusting bryozoans, and thick encrusting bryozoans (the latter including the species Hippaliosina depressa).

Specifically, the most represented groups were sponges with a total of 40 identified taxa, followed by algae with 14 taxa, bryozoans with 12 taxa, cnidarians (Hydrozoa and Anthozoa) with 10 taxa and molluscs (Bivalvia and vermetid Gastropoda) with 9 taxa. 
Table 1. Taxa recorded inside the 3 caves and corresponding abbreviations

\begin{tabular}{|c|c|c|c|c|c|}
\hline Rhodophyceae & & Dendroxea lenis & Dlen & Polychaeta & \\
\hline Amphiroa sp. & Amph & Diplastrella sp. & Dipl1 & Serpuloidea & Serp \\
\hline Encrusting corallines & Coral & Dysidea sp. & Dys1 & Bivalvia & \\
\hline Gelidiales & Gelid & Erylus euastrum & Eeua & Arca noae & Anoa \\
\hline Peyssonneliaceae & Peyss & Ircinia variabilis & Ivar & Chama gryphoides & Cgry \\
\hline Sphaerococcus coronopifolius & Scor & Merlia normani & Mnor & Gastrochaena dubia & Gdub \\
\hline Phaeophyceae & & Myrmekioderma spelaea & Mspe & Lima lima & Llim \\
\hline Dictyota dichotoma & Ddic & Oscarella sp. & Osc1 & Lithophaga lithophaga & Llith \\
\hline Halopteris filicina & Hfil & Paraplysilla spinifera & Par & Ostraeidae & Ostr1 \\
\hline Padina pavonica & Ppav & Penares helleri & Phel & Pygnodonta cochlear & Pcoc \\
\hline Chlorophyceae & & Petrosia ficiformis & Pfici & Spondylus gaederopus & Sgae \\
\hline Colpomenia sinuosa & Csin & Phorbas fictitius & $\begin{array}{l}\text { Pfict } \\
\text { Pten }\end{array}$ & Gastropoda & \\
\hline Palmophyllum crassum & Pcras & Phorbas tenacior & $\begin{array}{l}\text { Pten } \\
\text { Pdec }\end{array}$ & Vermetus sp. & Verm \\
\hline Valonia macrophysa & Vmac & $\begin{array}{l}\text { Placospongia decorticans } \\
\text { Plakina sp. }\end{array}$ & $\begin{array}{l}\text { Pdec } \\
\text { Plak }\end{array}$ & Cirripedia & \\
\hline Turf-forming algae & & Porifera sp. 1 & Por1 & Balanidae & Bar \\
\hline Filamentous dark algae & FDA & Porifera sp. 2 & Por2 & Bryozoa & \\
\hline Filamentous green algae & FGA & Porifera sp. 3 & Por3 & Encrusting thin bryozoans & EB1 \\
\hline Thin tubular sheet-like algae & TTS & Reniera sarai & Rsar & Encrusting thick bryozoans & EB2 \\
\hline Foraminifera & & Reniera sp.1 & Ren1 & Celleporidae & Cell \\
\hline Miniacina miniacea & Mmin & Sarcotragus spinulosus & Sspi & Cthenostomata & Cthe \\
\hline Porifera & & Spirastrella cunctatrix & Scun & Frondipora sp. & Frond \\
\hline Encrusting sponges & ES & Spirastrellidae & Spir & Lichenophora radiata & Lrad \\
\hline $\begin{array}{l}\text { Massive sponges } \\
\text { Marusting sponges }\end{array}$ & $\begin{array}{l}\text { ES } \\
\text { MS }\end{array}$ & Sycon sp. & Syc & Margaretta cereoides & Mcer \\
\hline Agelas oroides & Aoro & Terpios fugax & Tfug & Myriapora truncata & Mtru \\
\hline Aaptos aaptos & Aaap & Hydrozoa & & Pentapora sp. & Pent1 \\
\hline Acanthella acuta & $\mathrm{Aacu}$ & Hydroids & Hydr & Scrupocellaridae & Scrup \\
\hline Axinella sp. & Axin & Anthozoa & & Sertella septentrionalis & Ssep \\
\hline Chondrosia reniformis & Cren & Anthozoa sp. & Anth & Watersipora cucullata & Wcuc \\
\hline Clathria toxivaria & Ctox & Caryophyllia smithii & Csmi & Ascidiacea & \\
\hline Clathrina sp. 1 & Cla1 & Cereus pedunculatus & Cped & Ascidia sp. & Asc \\
\hline Clathrina clathrus & Cla & Cladocora caespitosa & Ccae & Aplidium conicum & Acon \\
\hline Cliona celata & Ccel & Clavularidae & Clav & Cystodytes dellechiaje & Cdel \\
\hline Cliona schmidti & Csch & Leptopsammia pruvoti & Lpru & Didemnum lahillei & Dlah \\
\hline Cliona spp. & Cli1 & Madracis pharensis & Mpha & Diplosoma listerianum & Dlist \\
\hline Corticium candelabrum & Ccan & Parazoanthus axinellae & Paxi & Pyura dura & Pdur \\
\hline Crambe crambe & Ccra & Polycyathus muellerae & Pmue & & \\
\hline
\end{tabular}

\section{Multivariate analyses}

PERMANOVA detected a significant $\mathrm{T} \times \mathrm{C} \times \mathrm{A}(\mathrm{S})$ interaction, indicating that differences in assemblage structure among areas within sectors varied across caves inconsistently with time (Table 2). Post hoc comparisons of assemblages among areas within each $\mathrm{T} \times \mathrm{C} \times \mathrm{S}$ combination revealed significant differences in 50 out of 60 sets of 3 tests each. Lack of differences among areas occurred mainly in CIO at S0 (T1), S10 (T4), S20 (T2, T3 and T4), S40 (T2) and S60 (T3 and T4); and in MAR and PRI at S40 (T2 and T1, respectively).

PERMANOVA also detected a significant $\mathrm{T} \times \mathrm{C} \times \mathrm{S}$ interaction, indicating that differences in assemblage structure across sectors varied with time and among caves (Table 2). Pairwise comparisons of sectors within each $\mathrm{T} \times \mathrm{C}$ combination (12 sets with 5 groups compared within each set, Table 3 ) revealed consistent significant differences between the assemblages at S0 (i.e. the entrance of the caves) and those at the inner parts of the caves (S40 and S60). Differences in assemblage structure among intermediate sectors (e.g. the comparisons S10 vs. S20 and/or S20 vs. S40) varied greatly across caves and times and were in some cases not interpretable (e.g. at PRI, T3).

nMDS plots of area centroids at the 4 sampling times reflected these general results (Fig. 2). A clear gradient of assemblage structure along the exterior-interior axis of each of the 3 caves was evident from all plots. With the only exception of PRI, where separation between S0 and S10 was less clearly depicted, areas within S0 were always distinct from areas in S40 and S60. Differences among intermediate sectors were less clear, with points referring to areas in different sectors often overlapping (Fig. 2).

Assemblage differences along the external-internal gradients were also highlighted by the CAP analyses (Table 4). The percentage of allocation success (i.e. all points correctly allocated into each group) was maximum at all sectors except S40 in CIO and at S0 and S60 
Table 2. PERMANOVA based on Bray-Curtis dissimilarities of $\log _{10}(x+1)$ transformed data from 94 variables. p-values were obtained using 4999 permutations of given permutable units. Terms already involved in significant higher order interactions were not analyzed. ${ }^{* *} \mathrm{p}<0.01$; $^{* * *} \mathrm{p}<0.001$

\begin{tabular}{|c|c|c|c|c|c|c|}
\hline $\begin{array}{l}\text { Source } \\
\text { of variation }\end{array}$ & $\mathrm{df}$ & SS & MS & $F$ & $\mathrm{p}$ & $\mathrm{MS}_{\mathrm{denom}}$ \\
\hline Time $=\mathrm{T}$ & 3 & 46822.9449 & 15607.6483 & & & \\
\hline Cave $=\mathrm{C}$ & 2 & 285575.0448 & 142787.5224 & & & \\
\hline Sector $=\mathrm{S}$ & 4 & 1306823.7668 & 326705.9417 & & & \\
\hline $\operatorname{Area}(\mathrm{A})=\mathrm{A}(\mathrm{S})$ & 10 & 29643.1769 & 2964.3177 & & & \\
\hline $\mathrm{T} \times \mathrm{C}$ & 6 & 72540.9071 & 12090.1512 & & & \\
\hline $\mathrm{T} \times \mathrm{S}$ & 12 & 78150.5525 & 6512.5460 & & & \\
\hline $\mathrm{T} \times \mathrm{A}(\mathrm{S})$ & 30 & 113402.0648 & 3780.0688 & & & \\
\hline $\mathrm{C} \times \mathrm{S}$ & 8 & 341975.5763 & 42746.9470 & & & \\
\hline $\mathrm{C} \times \mathrm{A}(\mathrm{S})$ & 20 & 58056.4046 & 2902.8202 & & & \\
\hline $\mathrm{T} \times \mathrm{C} \times \mathrm{S}$ & 24 & 150419.3346 & 6267.4723 & 1.4735 & $0.0116^{* *}$ & $\mathrm{~T} \times \mathrm{C} \times \mathrm{A}(\mathrm{S})$ \\
\hline $\mathrm{T} \times \mathrm{C} \times \mathrm{A}(\mathrm{S})$ & 60 & 255204.2938 & 4253.4049 & 3.3176 & $0.0002^{* * *}$ & Residual \\
\hline Residual & 1260 & 1615431.7963 & 1282.0887 & & & \\
\hline Total & 1439 & 4354045.8635 & & & & \\
\hline
\end{tabular}
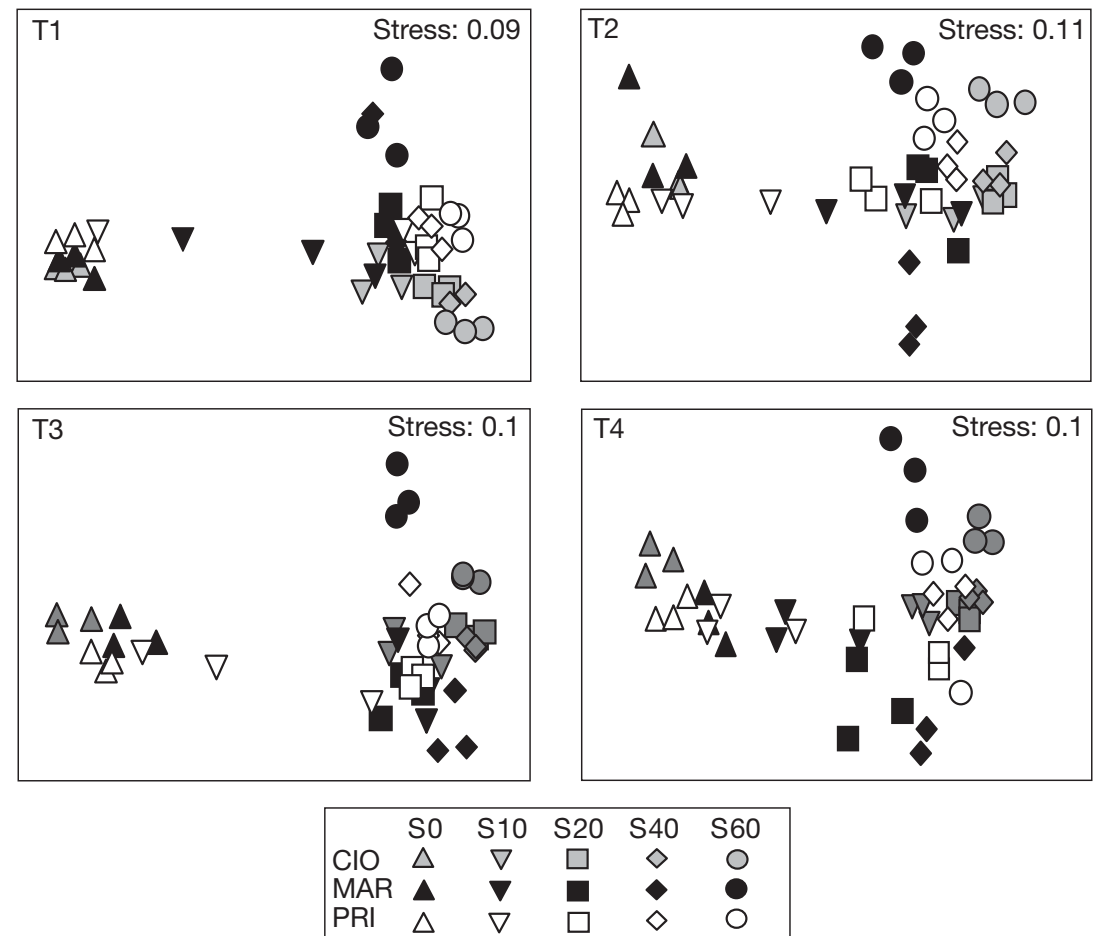

Fig. 2. nMDS plots showing differences of sessile benthos assemblages among caves, among sectors and among areas at the 4 sampling times (T1: July 2000; T2: November 2000; T3: February 2001; T4: June 2001). Each point represents the centroid of assemblages from 8 replicates based on the Bray-Curtis dissimilarities on $\log _{10}(x+1)$ - transformed data. S0, S10, S20, S40, S60: sector 0, 10, 20, 40, $60 \mathrm{~m}$ from cave entrance, respectively

in MAR. The lowest allocation success was achieved for the S10 groups in MAR and PRI. Particularly in the MAR data, the assemblage structures at S10 and S20 were not distinguishable from the analysis.

Several single variables were correlated with canonical axes in the CAP plots (Fig. 3). At S0, the groups of filamentous green algae, filamentous dark algae, red algae of the order Gelidiales, encrusting coralline and Peyssonneliaceae, and the encrusting green alga Palmophyllum crassum characterized the assemblages at all caves. The group of thin tubular sheet-like algae characterized the assemblage at CIO and PRI while Sphaerococcus coronopifolius and Valonia macrophisa characterized the assemblage at MAR and PRI. With respect to invertebrates, boring sponges of the genus Cliona spp. contributed to discriminate $\mathrm{S} 0$ in $\mathrm{CIO}$ and MAR, the boring bivalve Gastrochaena dubia and the group of the encrusting thin bryozoans were important in $\mathrm{CIO}$ and $\mathrm{MAR}$, respectively, whereas invertebrates were not important taxa in the entrance to PRI.

In more than one cave, a set of taxa was found which characterized the intermediate sectors (S10, S20 and S40). The boring bivalve Lithophaga lithophaga and the sponges Clathria toxivaria, Phorbas tenacior, Terpios fugax and Spirastrella cunctatrix were common to all 3 caves, while the anthozoan Polycyathus muellerae and a group of encrusting thick bryozoans characterized assemblages only in $\mathrm{CIO}$ and MAR intermediate sectors. Other sponges including Agelas oroides, Dendroxea lenis, Erylus euastrum, Penares helleri and the group of encrusting sponges were important in all 3 caves, but in PRI they characterized assemblages at S40 and S60. The sponge Cliona celata was associated with the most internal sector (S60) in MAR, and with intermediate sectors (S10 and S20) in PRI. The sponge Diplastrella sp. and the group of polychaetes Serpuloidea characterized the inner sectors in all 3 caves. The sector S60 was characterized by Myrmekioderma spelaea only in CIO and PRI, and by Placospongia decorticans and Aaptos aaptos only in MAR and PRI.

Several characterizing taxa were found exclusively in one cave. In CIO, these were the sponges Clathrina 
Table 3. Results of multivariate pairwise comparisons between the 5 sectors at each cave and time (T1: July 2000; T2: November 2000; T3: February 2001; T4: June 2001) (following the significant $\mathrm{T} \times \mathrm{C} \times \mathrm{S}$ term shown in Table 2). See Fig. 1 for full cave names

\begin{tabular}{|lllll|}
\hline Cave & \multicolumn{1}{c}{ T1 } & \multicolumn{1}{c}{ T2 } & \multicolumn{1}{c|}{ T3 } & \multicolumn{1}{c|}{ T4 } \\
\hline CIO & $0 \neq 10=20=40 \neq 60$ & $0 \neq 10=20=40 \neq 60$ & $0 \neq 10=20 \neq 40 \neq 60$ & $0 \neq 10=20=40 \neq 60$ \\
& $10 \neq 40$ & & $10 \neq 40$ \\
MAR & $0 \neq 10=20=40 \neq 60$ & $0 \neq 10=20 \neq 40 \neq 60$ & $0 \neq 10=20 \neq 40 \neq 60$ & $0 \neq 10=20=40 \neq 60$ \\
PRI & $0=10 \neq 20 \neq 40 \neq 60$ & $0=10 \neq 20=40=60$ & $0=10 \neq 20 \neq 40 \neq 60$ & $0=10 \neq 20 \neq 40=60$ \\
& $10=20=40=60$ & & $10=20 \neq 40 \neq 60$ & $60=20$ \\
& & & $20=40 \neq 60$ & \\
& & & & \\
& & & & \\
\hline
\end{tabular}

$\times \mathrm{C} \times \mathrm{S}$ (Table 5), indicating differences among and within sectors that changed interactively with time and across caves.

SNK tests and visual inspection of graphs (Fig. 4) suggested that the mean number of taxa did not change in parallel with the exterior-interior axis of the caves. At MAR, the lowest values were recorded at $\mathrm{S} 60$ at all sampling times. Such a pattern, however, was reversed at CIO, where the richness of taxa was lowest at S0. Differences were also not interpretable according to the axis at PRI, where the

clathrus in the intermediate sectors, and Clathrina sp. 1, Corticium candelabrum, Plakina sp., Reniera sarai, and Reniera sp. at S60. In MAR, exclusive taxa were found at S10, S20, and S40; the sponge Merlia normani, the anthozoan Leptopsammia pruvoti, the gastropod Vermetus sp., the bryozoan Watersipora cucullata, and a suite of species belonging to the families Scrupocellaridae and Celleporidae. In PRI, assemblages at S10 and S20 were characterized by the sponge Phorbas fictitius, the anthozoan Parazoanthus axinellae and the ascidian Cystodytes dellechiaje.

\section{Univariate analyses}

The analysis of mean number of taxa detected the significance of the interaction terms $\mathrm{T} \times \mathrm{C} \times \mathrm{A}(\mathrm{S})$ and $\mathrm{T}$ highest mean number of taxa was recorded at S20, the lowest at S0.

The analysis of percent substrate cover by algae and sessile animals detected a significant $\mathrm{T} \times \mathrm{C} \times$ A(S) interaction term, suggesting significant differences among areas that varied across sectors and caves, inconsistently with time (Table 5). The analyses also highlighted the significance of the term $\mathrm{C} \times \mathrm{S}$ (Table 5), suggesting that changes in percentage cover among sectors were not consistent across caves. Comparisons of sectors within each level of the factor Cave indicated a clear pattern of reduction in substrate cover from the entrance to the inner part of the cave only at MAR (Fig. 5). At both CIO and PRI, differences in percent cover among sectors were complex and not interpretable according to the exteriorinterior axis.

Table 4. Results of CAP analyses examining effects of sector within each of the 3 caves (see Fig. 1). m: no. of PCO axes used in the CAP procedure; \% var: percentage of total variance explained by PCO axes; $\delta^{2}{ }_{1}$ and $\delta^{2}{ }_{2}$ the squared canonical correlations for the 2 canonical axes; \% All. Succ.: percentage of points correctly allocated into each group

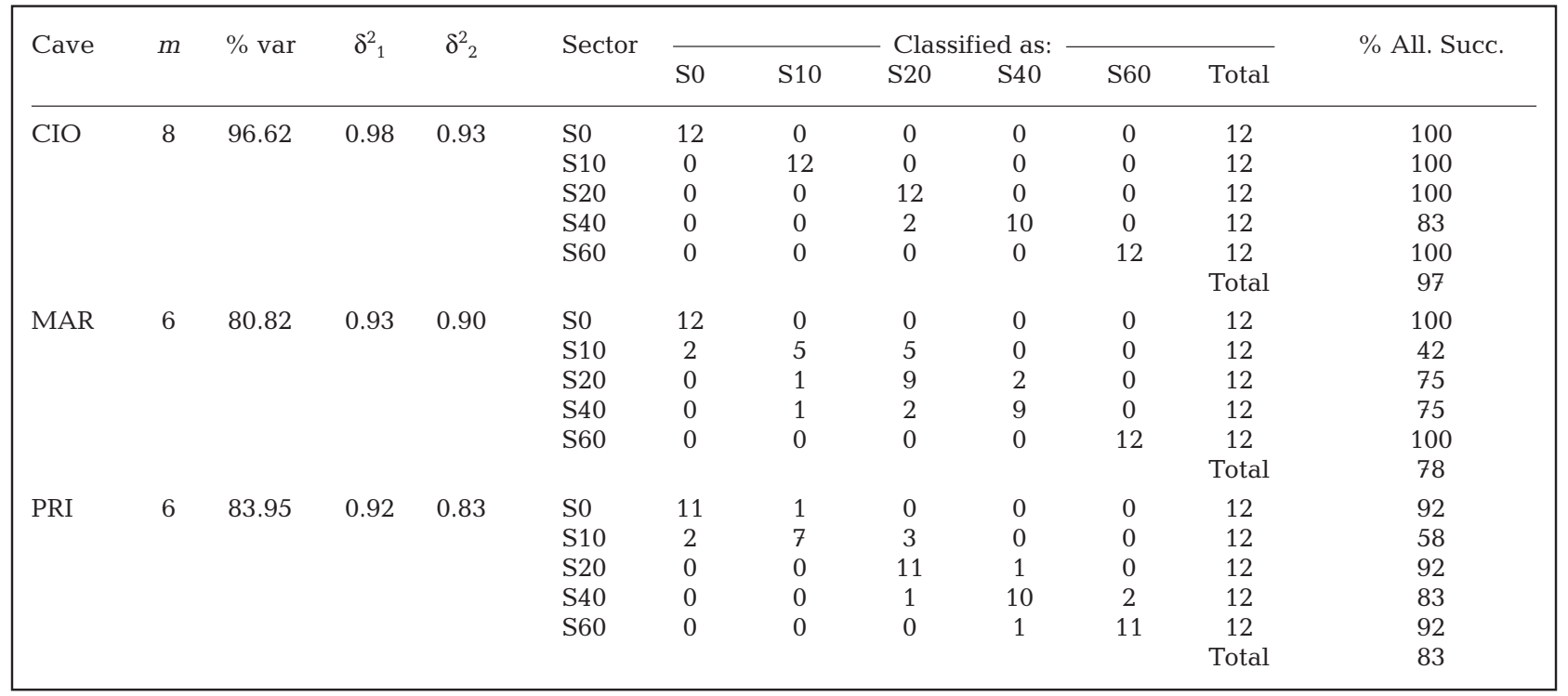



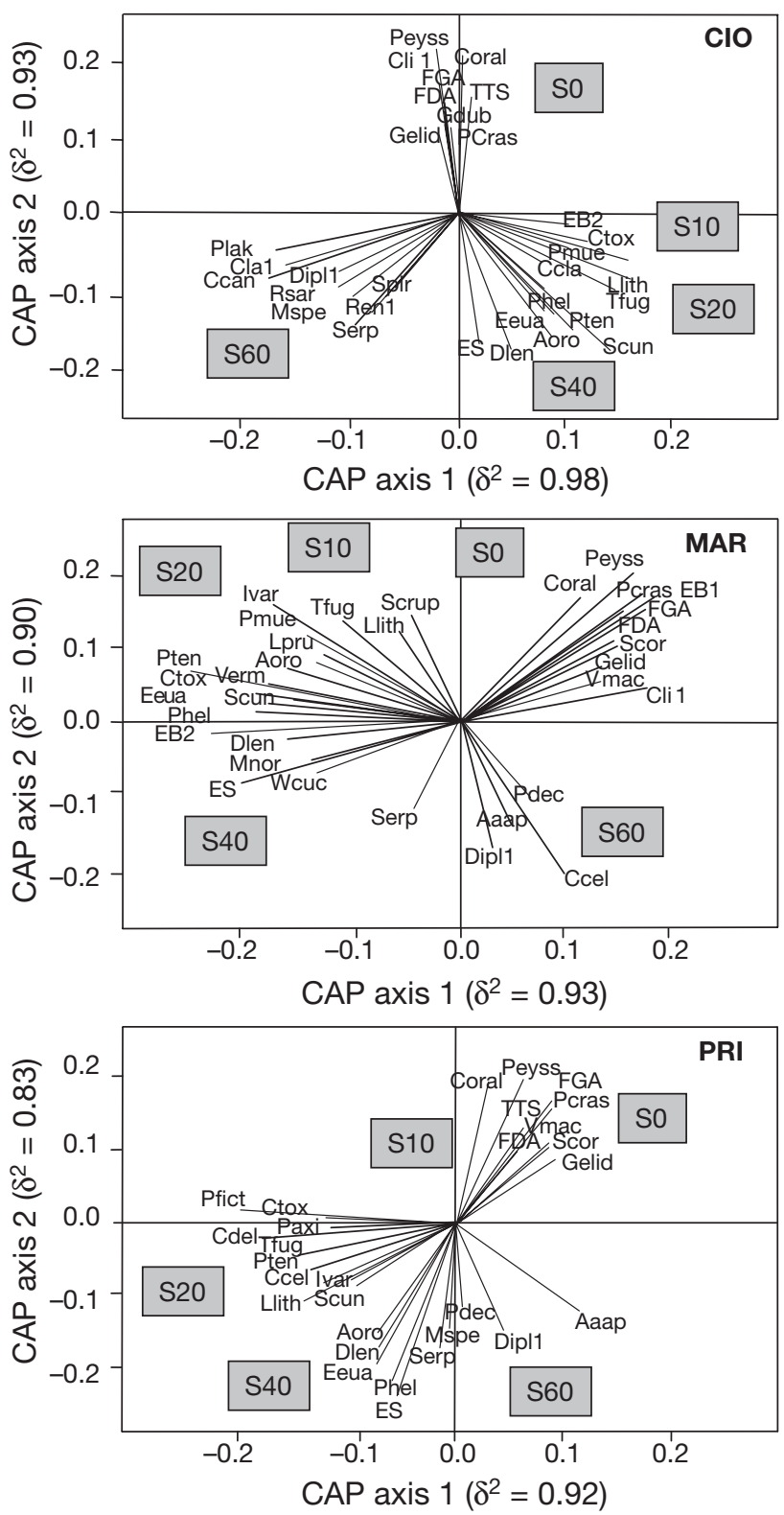

Fig. 3. CAP plots showing canonical axes that best discriminate assemblages at the 5 different sectors. See Table 1 for definition of taxonomical abbreviations

\section{DISCUSSION}

The results of this study indicate that the structure of the assemblages changed sharply along the exterior-interior axis of the 3 caves, with some taxa occurring at some distances from the entrance but not at others. Several taxa were recorded from only one cave and, often, different taxa characterized equivalent sectors in the 3 caves. However, the general pattern of differences along the gradient was not consistent in time and across caves and was blurred by differences in assemblage structure occurring among areas within sectors. Our results therefore suggest that highly complex processes govern such spatio-temporal distribution patterns and that most of the ecological processes commonly invoked as major determinants of the structure of natural assemblages are context- and scaledependent.

Differences in benthic assemblages along the exterior-interior axis of the 3 caves reflect a common pattern, already reported in the literature by several authors (e.g. Cinelli et al. 1977, Balduzzi et al. 1989, Zabala et al. 1989). Red encrusting and filamentous green algae characterized the entrances of the 3 caves for about $10 \mathrm{~m}$ inwards. Probably related to the absence of other successful competitors such as algae, sponges were quantitatively dominant in the intermediate and inner sectors. Moreover, encrusting forms of sponges characterized the innermost sectors of all caves, as observed also by Bell (2002) on the cliff walls of an Atlantic marine cave. We have not provided measures of current velocity inside the caves but the presence of these growth forms, which resist dislodging in fast and turbulent flow regimes (Bell \& Barnes 2000) leads us to hypothesize that in some cases fast currents and turbulent flows may characterize even shallow blind caves, in contrast with the classical model of reduced hydrodynamic regime from the entrance towards the inner portions.

Although the horizontal zonation clearly emerges as a main pattern in the 3 caves, a simple gradient alone cannot explain all the variability observed in sessile benthos among areas within sectors. This result is not surprising since all the recent attempts at describing the distribution of populations and species assemblages along environmental gradients unequivocally showed the presence of other sources of variation influencing both spatial and temporal distribution patterns of benthic organisms (Benedetti-Cecchi et al. 1998, Menconi et al. 1999, Benedetti-Cecchi 2001, Giangrande et al. 2003, Terlizzi et al. 2003, in press, Fraschetti et al. 2005). Inside a single cave, Airoldi \& Cinelli (1996) detected small-scale spatial variability of fluxes of particulate material. From this perspective, small-scale heterogeneity inside caves (e.g. small protuberances, hollows, flats, silt deposits on walls) may lead to microhabitat complexity affecting recruitment and biological interactions of established organisms (Balduzzi et al. 1989, Benedetti-Cecchi et al. 1996).

The role of competition in influencing the distribution of cave benthic assemblages is largely unknown, notwithstanding its recognized importance in affecting natural communities at small spatial scales (Jackson 1977, Buss \& Jackson 1979, Sebens 1982). Buss \& Jackson (1981) stressed the potential for competition for food in cryptic epibenthic fauna when high levels of depletion occur. Inside caves, Benedetti-Cecchi et 
Table 5. Results of analyses of variance on mean number of taxa and percentage cover of benthic organisms. Terms already involved in significant interactions were not analyzed. ns: not significant; ${ }^{* *} \mathrm{p}<0.01,{ }^{* * *} \mathrm{p}<0.001$

\begin{tabular}{|c|c|c|c|c|c|}
\hline \multirow{2}{*}{$\begin{array}{l}\text { Source } \\
\text { of variation }\end{array}$} & \multirow[t]{2}{*}{$\mathrm{df}$} & \multicolumn{2}{|c|}{ No. of taxa } & \multicolumn{2}{|c|}{ Total cover } \\
\hline & & MS & $F$ & MS & $F$ \\
\hline Time $=\mathrm{T}$ & 3 & 127.95 & & 4660.48 & \\
\hline Cave $=\mathrm{C}$ & 2 & 294.87 & & 5833.24 & \\
\hline Sector $=\mathrm{S}$ & 4 & 1425.26 & & 42350.34 & \\
\hline Area $=\mathrm{A}(\mathrm{S})$ & 10 & 37.85 & & 465.51 & \\
\hline $\mathrm{T} \times \mathrm{C}$ & 6 & 34.70 & & 835.34 & \\
\hline $\mathrm{T} \times \mathrm{S}$ & 12 & 31.00 & & 1401.44 & \\
\hline $\mathrm{T} \times \mathrm{A}(\mathrm{S})$ & 30 & 18.78 & & 585.35 & \\
\hline $\mathrm{C} \times \mathrm{S}$ & 8 & 357.89 & & 9844.18 & $27.80^{* * *}$ \\
\hline $\mathrm{C} \times \mathrm{A}(\mathrm{S})$ & 20 & 16.70 & & 535.74 & \\
\hline $\mathrm{T} \times \mathrm{C} \times \mathrm{S}^{\mathrm{a}}$ & 24 & 25.20 & $1.87^{* *}$ & 738.18 & 1.49 \\
\hline $\mathrm{T} \times \mathrm{C} \times \mathrm{A}(\mathrm{S})$ & 60 & 13.48 & $1.87^{* * *}$ & 495.38 & $1.83^{* * *}$ \\
\hline Residual & 1260 & 7.21 & & 271.18 & \\
\hline Total & 1439 & & & & \\
\hline Cochran Test & & $0.02^{\text {ns }}$ & & $0.18^{\text {ns }}$ & \\
\hline Transformation & & None & & None & \\
\hline
\end{tabular}

al. (1996, 1998) revealed the superior competitive ability of the larger organisms (i.e. the sponge Geodia cydonium) but also suggested a mechanism of competition through pre-emption of the substratum: once adults gain access to space, they cannot be competi- tively displayed and maintain their dominance for an extended period (Connell \& Slatyer 1977, Underwood \& Denley 1984). Biotic interactions, therefore, may largely contribute to the heterogeneity among (and within) caves.

Trends of total cover were not consistent with previous observations of a progressive decrease in total cover from the entrance towards the inner portions of blind caves (e.g. Harmelin et al. 1985, Gili et al. 1986, Balduzzi et al. 1989, Corriero et al. 2000). Whereas in MAR total cover in the innermost sector was significantly lower than in the outer sectors, high total covers were found in the inner sectors of the CIO and PRI caves. Furthermore, hydroids of the genus Eudendrium were also observed in the dark inner reaches of MAR. Boero (1985) and Balduzzi at al. (1989) suggested that the penetration of passive suspension-feeders such as hydroids inside marine caves is limited by conditions of insufficient water renewal. Given the presence of these organisms, an abrupt decline of water renewal is unlikely to have occurred
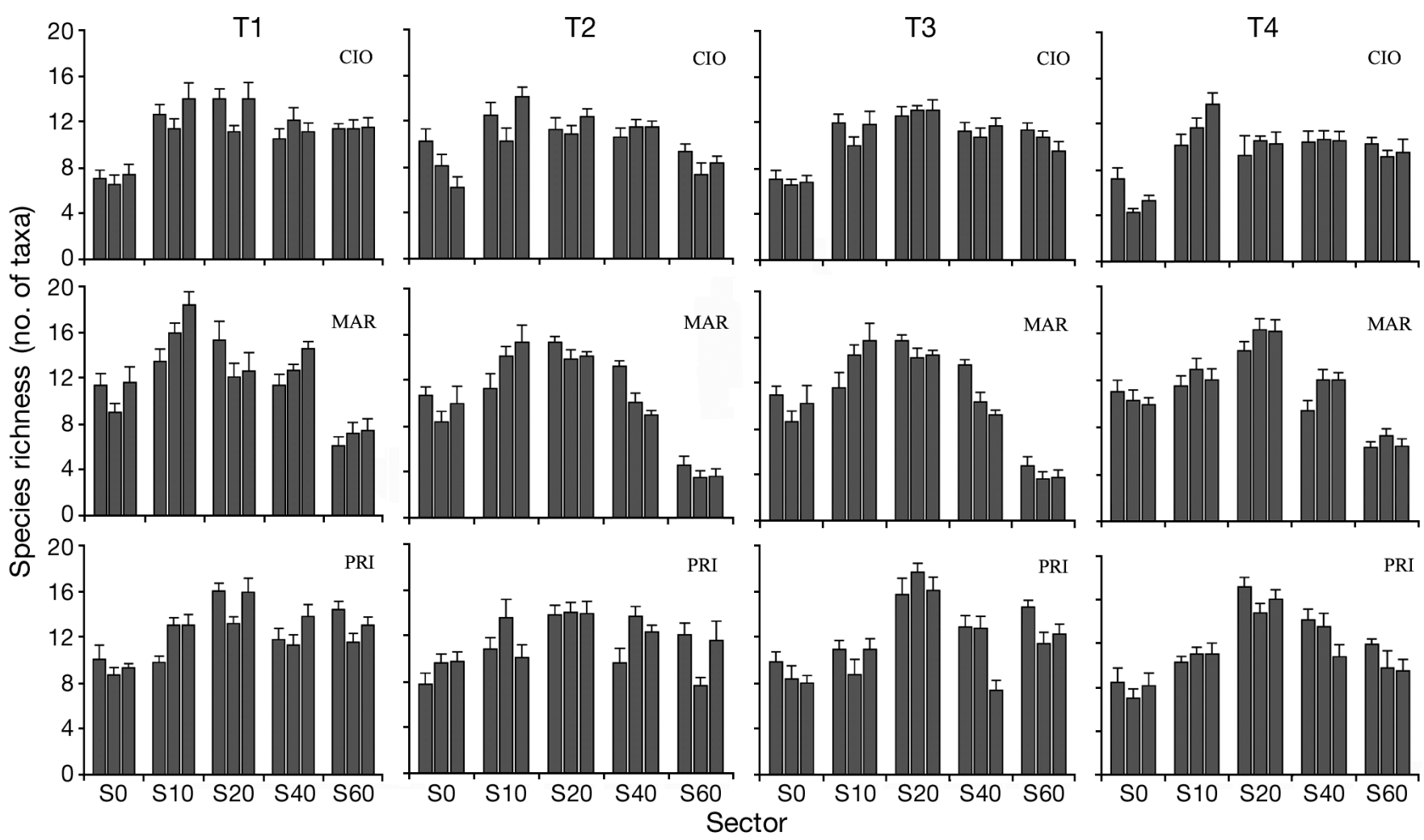

Fig. 4. Spatial and temporal patterns of species richness (mean number of taxa $\pm \mathrm{SE}, \mathrm{n}=8$ ). For each sector, 3 areas were sampled 


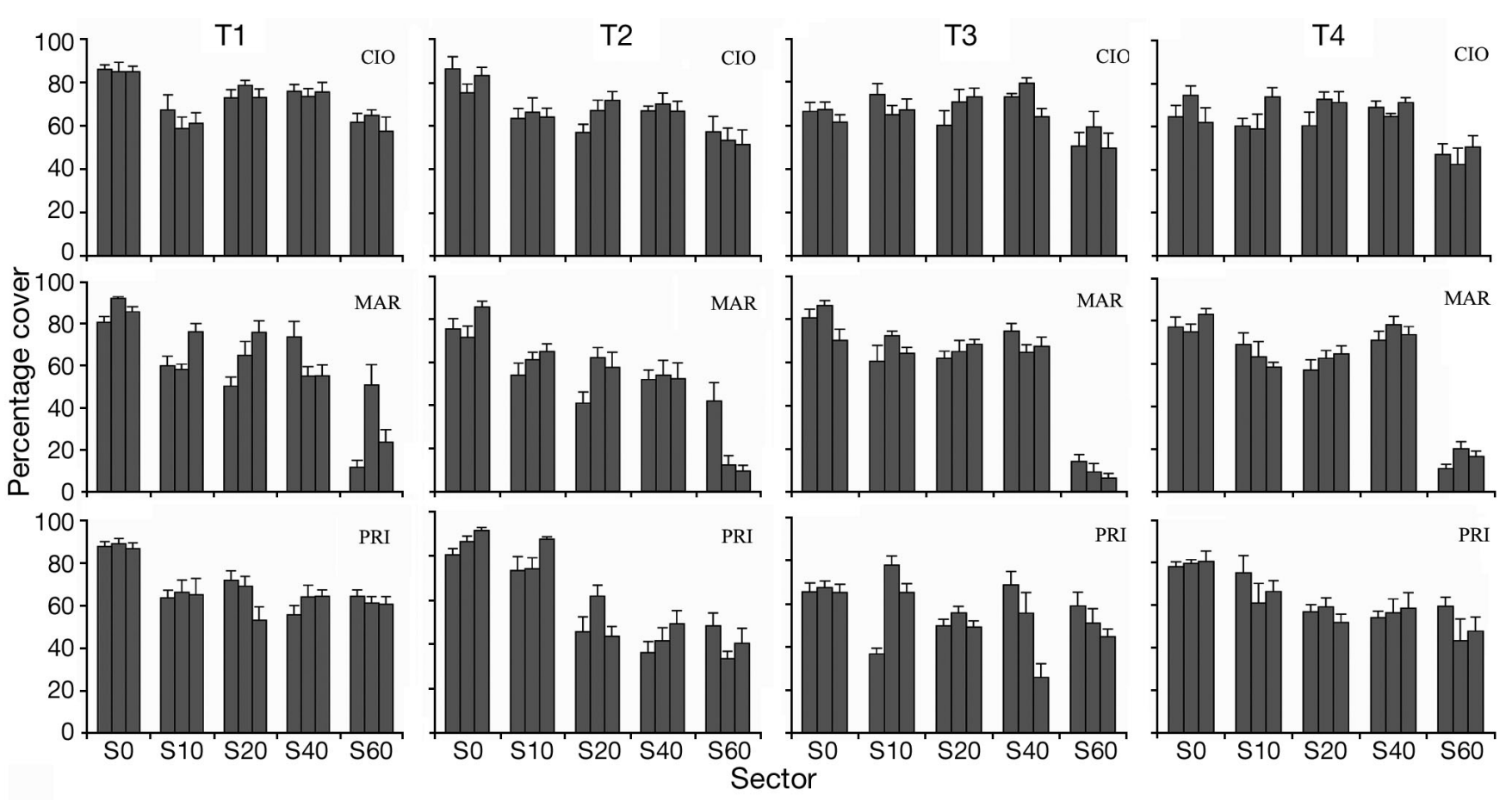

Fig. 5. Spatial and temporal patterns of percentage substratum covered by algae and sessile animals $($ mean $\pm S E, n=8)$

and a decline in food availability in the inner part of the cave should be excluded.

The differences among caves might depend on local differences in species distribution outside the caves. Several taxa characterizing the outermost sectors of the 3 caves are common in the subtidal rocky reefs of the same stretch of coast (Fraschetti et al. 2001, Terlizzi et al. in press). However, a suite of taxa was exclusive to each cave and, in general, the organisms most responsible for the high heterogeneity among caves inhabited the inner portions (e.g. the encrusting cheilostome bryozoan Watersipora cucculata, the sponges Corticium candelabrum and Placospongia decorticans, and the ascidian Cystodites dellechjaie). Results suggest that peculiar features characterize each cave, and also indicated a substantially low temporal variability in the structure of assemblages. Similar considerations are reported in the literature: Sarà (1978) stressed that assemblages of marine caves generally show a high degree of individuality. Harmelin (1985) suggested that the relative stability of environmental factors in the inner portions of the caves (Riedl 1966, Harmelin et al. 1985, Bianchi et al. 1996) could facilitate the persistence of populations well represented in certain caves but absent or rare in adjacent ones.

The caves we investigated were rather close to each other, so differences in larval dynamics due to largescale hydrographic processes can be excluded. Species with short-lived larvae can have patchy distribu- tion, being strongly affected by the location of source populations (Bingham 1992, Fraschetti et al. 2003) but such aspects require further investigation inside caves. For instance, encrusting cheilostome bryozoans are good competitors for space, but they have low recruitment rates (McKinney \& Jackson 1989, Herrera et al. 1996); in addition sponge and ascidian larvae are generally reported as short-lived (Svane \& Young 1989, Maldonado \& Bergquist 2002). Encrusting cheilostome bryozoans (such as the bryozoan Hippoliosina depressa) and some sponge species (e.g. Plakina sp.) were found in only one cave. Harmelin (1997) suggested that the occurrence of some bryozoan species in caves from the Provence region (France, Mediterranean Sea) could be related to low dispersal capability. Muricy et al. (1996), studying sponges of the genus Plakina in the same region, hypothesized that marine caves may function as islands supporting isolated populations.

Uniqueness is an important requisite to set conservation priorities, especially for those ecological systems that, at present, are among the few marine habitats protected by the European Community (Habitat Directive 92/43 EEC). Since, from our results, peculiar benthic assemblages inhabit each cave, much deeper knowledge of these unique systems is needed to make decisions about which and how many caves need protection, so as to include proper representation of species and the relevant ecological processes operating in the different caves. 
In conclusion, the present results are consistent with previous findings of the influence of environmental gradients on the distribution of cave benthos, but suggest that generalizations of results from a single cave, are not appropriate since multiple and interactive ecological processes shape cave assemblages in complex ways. Unravelling the interplay of different abiotic and biotic factors acting at different spatial and temporal scales remains a major challenge in these environments.

Acknowledgements. Research funded by the 'Regione Puglia' INTERREG II Italy-Greece, and MIGORIAP projects. The network of excellence 'Marine Biodiversity and Ecosystem Functioning' (MARBEF) funded by the European Community Sixth Framework Programme (contract no. GOCE-CT-2003505446) provided further support. The paper benefited from discussions during the training course (partially funded by MARBEF) 'Biodiversity, phylogeny and ecology of Porifera' held at Station Marine d'Endoume (France) in July 2005. Identification of dubious specimens was performed by: $\mathrm{M}$. Catra and M. Cormaci (algae); C. Cerrano and K. Longo (sponges); H. Zibrowius (anthozoans); C. Chimenz (bryozoans); and F. Mastrototaro (ascidians). M. Metrangolo and L. Muscogiuri assisted with the analysis of slides. F. Denitto, A. Costantini, R. Onorato, M. Poto and C. Vaglio provided invaluable help during fieldwork. The final version of this manuscript greatly benefited from comments made by $\mathrm{F}$. Micheli and 2 anonymous referees.

\section{LITERATURE CITED}

Airoldi L, Cinelli F (1996) Variability of fluxes of particulate material in a submarine cave with chemolithoautotrophic inputs of organic carbon. Mar Ecol Prog Ser 29:205-217

Airoldi L, Cinelli F (1997) Sources and biochemical composition of suspended particulate material in a submarine cave with sulphur water springs. Mar Biol 128:537-545

Anderson MJ (2001) A new method for non-parametric multivariate analysis of variance. Aust Ecol 26:32-46

Anderson MJ, ter Braak CJF (2003) Permutation tests for multi-factorial analysis of variance. J Statist Comp Sim 73: 85-113

Anderson MJ, Willis TJ (2003) Canonical analysis of principal coordinates: a useful method of constrained ordination for ecology. Ecology 84:511-525

Balduzzi A, Bianchi CN, Boero F, Cattaneo R, Pansini M, Sarà $M$ (1989) The suspension-feeder communities of a Mediterranean sea cave. In: Ros JD (ed) Topics in marine biology. Proc 22nd Eur Mar Biol Symp, Barcelona, Spain, August 1987. Sci Mar 53:387-395

Bell JJ (2002) The sponges community in a semi-submerged temperate sea cave: density, diversity and richness. PSZN I: Mar Ecol 23:297-311

Bell JJ, Barnes DKA (2000) The influence of bathymetry and flow regime upon the morphology of sublittoral sponge communities. J Mar Biol Assoc UK 80:707-718

Benedetti-Cecchi L (2001) Variability in abundance of algae and invertebrates at different spatial scales on rocky sea shores. Mar Ecol Prog Ser 215:79-92

Benedetti-Cecchi L, Airoldi L, Abbiati M, Cinelli F (1996) Exploring the causes of spatial variation in an assemblage of benthic invertebrates from a submarine cave with sul- phur springs. J Exp Mar Biol Ecol 208:153-168

Benedetti-Cecchi L, Airoldi L, Abbiati M, Cinelli F (1998) Spatial variability in the distribution of sponges and cnidarians in a sublittoral marine cave with sulphur-water springs. J Mar Biol Assoc UK 78:43-58

Bianchi CN, Cattaneo-Vietti R, Cinelli F, Morri C, Pansini M (1996) Lo studio biologico delle grotte sottomarine del Mediterraneo: conoscenze attuali e prospettive. Boll Mus Ist Biol Univ Genova 60-61:41-69

Bingham (1992) Life histories in an epifaunal community: coupling of adult and larval processes. Ecology 73: 2244-2259

Boero F (1985) Hydroid zonation along a marine cave of the Penisola Sorrentina (Gulf of Naples). Rapp Comm Int Mer Médit 29:135-136

Boero F (1994) Fluctuations and variations in coastal marine environments. PSZN I: Mar Ecol 15:3-25

Boero F, Belmonte G, Bussotti S, Fanelli G and 11 others (2004) From biodiversity and ecosystem functioning to the roots of ecological complexity. Ecol Compl 2:101-109

Brown JH (1995) Macroecology. University of Chicago Press, Chicago, IL

Buss LW, Jackson JBC (1979) Competitive networks: nontransitive competitive relationships in cryptic coral reef environments. Am Nat 113:223-234

Buss LW, Jackson JBC (1981) Planktonic food availability and suspension feeder abundance: evidence of in situ depletion. J Exp Mar Biol Ecol 49:151-161

Bussotti S, Denitto F, Guidetti P, Belmonte G (2002) Fish assemblages in shallow marine caves of the Salento Peninsula (Southern-Apulia, SE Italy). PSZN I: Mar Ecol 23:11-20

Chevaldonné P, Lejeusne C (2003) Regional warminginduced species shift in north-west Mediterranean marine caves. Ecol Lett 6:371-379

Cicogna F, Bianchi CN, Ferrari G, Forti P (2003) Grotte marine: cinquant'anni di ricerca in Italia. CLEM, Ministero dell'Ambiente e della tutela del Territorio, Canessa Editore, Rapallo

Cinelli F, Fresi E, Mazzella L, Pronzato M, Pansini M, Svoboda A (1977) Distribution of benthic phyto- and zoocoenoses along a light gradient in a superficial marine cave. In: Keegan BF, O'Céidigh P, Boaden PJS (eds) Biology of benthic organisms. Pergamon Press, Oxford, p 173-183

Connell JH, Slatyer RO (1977) Mechanism of succession in natural communities and their role in community stability and organization. Am Nat 111:1119-1144

Corriero G, Scalera Liaci L, Ruggiero D, Pansini M (2000) The sponge community of a semi-submerged Mediterranean cave. PSZN I: Mar Ecol 21:85-96

Dethier MN, Graham ES, Cohen S, Tear LM (1993) Visual versus random-point percent cover estimations: 'objective' is not always better. Mar Ecol Prog Ser 96:93-100

Fichez R (1990) Decrease in allochthonous organic inputs in dark submarine caves, connection with lowering in benthic community richness. Hydrobiologia 207:61-69

Fraschetti S, Bianchi CN, Terlizzi A, Fanelli G, Morri C, Boero F (2001) Spatial variability and human disturbance in shallow subtidal hard substrate assemblages: a regional approach. Mar Ecol Prog Ser 212:1-12

Fraschetti S, Giangrande A, Terlizzi A, Boero F (2003) Preand post-settlement events in benthic community dynamics. Oceanol Acta 25:285-295

Fraschetti S, Terlizzi A, Benedetti-Cecchi L (2005) Patterns of distribution of marine assemblages from rocky shores: evidence of relevant scales of variation. Mar Ecol Prog Ser 296:13-29 
Garrabou J, Flos J (1995) A simple diffusion-sedimentation model to explain planktonic gradients within a NW Mediterranean submarine cave. Mar Ecol Prog Ser 123:273-280

Gaston KJ, McArdle BH (1993) Measurement of variation in the size of populations in space and time: some points of clarifications. Oikos 68:357-360

Giangrande A, Delos AL, Fraschetti S, Musco L, Licciano M, Terlizzi A (2003) Polychaete assemblages of rocky shore along the South Adriatic coast (Mediterranean Sea): pattern of spatial distribution. Mar Biol 143:1109-1116

Gili JM, Riera T, Zabala M (1986) Physical and biological gradients in a submarine cave on the Western Mediterranean coast (North-East Spain). Mar Biol 90:291-297

Harmelin JG (1969) Bryozoaires des grottes sous marines obscures de la région Marseillaise. Faunistique et écologie. Téthys 11:214-229

Harmelin JG (1985) Organisation spatiale des communautés sessiles des grottes sous-marines de Mèditerranée. Rapp Comm Int Mer Médit 5:149-153

Harmelin JG (1997) Diversity of bryozoans in a Mediterranean sublittoral cave with bathyal-like conditions: role of dispersal processes and local factors. Mar Ecol Prog Ser 153:139-152

Harmelin JG, Vacelet J (1997) Clues to deep-sea biodiversity in a nearshore cave. Vie Milieu 47:351-354

Harmelin JG, Vacelet J, Vasseur P (1985) Les grottes sousmarines obscures: un milieu extrême et un remarquable biotope refuge. Tethys 11:214-229

Herrera A, Jackson JBC, Hugues DJ, Jara J, Ramos H (1996) Life-history variation inthree coexisting cheilostome bryozoan species of the genus Stylopoma in Panamá. Mar Biol 126:461-469

Hurlbert SH (1984) Pseudoreplication and the design of ecological experiments. Ecol Monogr 54:187-211

Jackson JBC (1977) Competition on marine hard substrata. The adaptative significance of solitary and colonial strategies. Am Nat 111:743-768

Laborel J, Vacelet J (1958) Étude des peuplements d'une grotte sous-marine du golfe de Marseille. Bull Inst Oceanogr 55:1-20

Lachenbruch PA, Mickey MR (1968) Estimation of error rates in discriminant analysis. Technometrics 10:1-11

Levin SA (1992) The problem of pattern and scale in ecology. Ecology 73:1943-1967

Maldonado M, Bergquist PR (2002) Phylum Porifera. In: Young CM (ed) Atlas of marine invertebrate larvae. Academic Press, London, p 21-50

Martì R, Uriz MJ, Ballesteros E, Turon X (2004a) Benthic assemblages in two Mediterranean caves: species diversity and coverage as a function of abiotic perameters and geographic distance. J Mar Biol Assoc UK 84:557-572

Martì R, Uriz MJ, Ballesteros E, Turon X (2004b) Temporal variation of several structure descriptors in animaldominated benthic communities in two Mediterranean caves. J Mar Biol Assoc UK 84:573-580

McArdle BH, Anderson MJ (2001) Fitting multivariate models to community data: a comment on distance-based redundancy analysis. Ecology 82:290-297

Editorial responsibility: Erik Bonsdorff (Contributing Editor), Turku/Åbo, Finland
McKinney FK, Jackson JBC (1989) Bryozoan evolution Unwin Hyman, Boston, MA

Menconi M, Benedetti-Cecchi L, Cinelli F (1999) Spatial and temporal variability in the distribution of algae and invertebrates on rocky shores in the northwest Mediterranean. J Exp Mar Biol Ecol 233:1-23

Muricy G, Solé-Cava AM, Thorpe JP, Boury-Esnault N (1996) Genetic evidence for extensive cryptic speciation in the subtidal sponge Plakina trilopha (Porifera: Demospongiae: Homoscleromorpha) from the Western Mediterranean. Mar Ecol Prog Ser 138:181-187

Ott JA, Svoboda A (1976) Sea caves as model systems for energy flow studies in primary hard bottom communities. Pubbl Stn Zool Napoli 40:477-485

Palau M, Cornet C, Riera T, Zabala M (1991) Planktonic gradients along a Mediterranean Sea cave. In: Ros JD, Prat N (eds) Homage to R. Margalef or Why there is such pleasure in studying nature. Oecol Aquat 10:299-316

Pérès JM, Picard J (1964) Nouveau manuel de bionomie benthique de la Mer Méditérraneè. Recl Trav Stn Mar Endoume Fac Sci Mars 47:5-137

Riedl R (1966) Biologie der Meereshohlen. Paul Parey, Hamburg

Sarà M (1978) Il popolamento delle grotte marine e sua protezione: interesse di una salvaguardia. Pubbl Stn Zool Napoli 40:502-505

Schneider DC (1994) Quantitative ecology. Academic Press, San Diego, CA

Sebens KP (1982) Competition for space: growth rate, reproductive output, and escape in size. Am Nat 15:353-391

Steneck RL, Dethier MN (1994) A functional group approach to the structure of algal-dominated communities. Oikos 69:476-498

Svane I, Young CM (1989) The ecology and behaviour of ascidian larvae. Mar Biol Annu Rev 27:45-90

Terlizzi A, Scuderi D, Fraschetti S, Guidetti P, Boero F (2003) Molluscs on subtidal cliffs: patterns of spatial distribution. J Mar Biol Assoc UK 82:1-8

Terlizzi A, Anderson MJ, Fraschetti S, Benedetti-Cecchi L (in press) Scales of spatial variation in Mediterranean subtidal sessile assemblages at different depths. Mar Ecol Prog Ser

Underwood AJ (1997) Experiments in ecology: their logical design and interpretation using analysis of variance. University Press, Cambridge

Underwood AJ, Denley EJ (1984) Paradigms, explanations and generalizations in models for the structure of intertidal communities on rocky shores. In: Strong DR, Simberloff D, Abele LG, Thistle A (eds) Ecological communities: conceptual issues and the evidence. Princeton University Press, Princeton, NJ, p 151-180

Winer BJ, Brown DR, Michels KM (1991) Statistical principles in experimental designs, 3rd edn. McGraw-Hill, Sydney

Zabala M, Riera T, Gili JM, Barangé $M$, Lobo A, Peñuelas J (1989) Water flow, trophic depletion, and benthic macrofauna impoverishment in a submarine cave from the Western Mediterranean. PSZN I: Mar Ecol 10:271-287

Submitted: January 13, 2006; Accepted: April 7,2006 Proofs received from author(s): October 24, 2006 